Bayero Journal of Pure and Applied Sciences, 5(2): 143 - 147

Received: November 2012

Accepted: December 2012

ISSN $2006-6996$

\title{
TRACE METAL CONCENTRATIONS IN LEACHATES FROM OPEN DUMPSITES IN LOKOJA, KOGI STATE, NIGERIA
}

\author{
Olarewaju, G.O., Sa'id, M.D. and Ayodele, J.T. \\ Department of Pure and Industrial Chemistry, Bayero University, Kano, P.M.B 3011, \\ Kano-Nigeria \\ Correspondence author: dayyibmds@yahoo.com
}

\begin{abstract}
Leachates from selected dumpsites and control site in Lokoja municipal were analyzed for trace metal concentrations. These parameters were compared with control samples and established international standards (FEPA) and (WHO). Dumpsite leachates contained very high concentrations of iron $(73.60 \pm 0.58) \mathrm{mg} / \mathrm{L}$, manganese $(16.53 \pm 0.309) \mathrm{mg} / \mathrm{L}$, copper $1.00 \pm 0.02 \mathrm{mg} / \mathrm{L}$, zinc $2.41 \pm 0.042 \mathrm{mg} / \mathrm{L}$, and lead $1.55 \pm 0.097 \mathrm{mg} / \mathrm{L}$. All the parameters except nickel and cadmium were above the control and exceed FEPA and WHO guidelines. The study revealed that the dumpsite is a major polluting source in the surrounding environment. This underlines the need for appropriate government agency of Kogi State, Nigeria to initiate active remediation process such as phytoremediation in combination with physiochemical methods to recover the dumpsite from contaminants and reduce the level of pollution in the surrounding environment.
\end{abstract}

Keywords: Leachates, dumpsite, remediation, phyto remediation, trace metals.

\section{INTRODUCTION}

Pollution occurs when a product added to our natural environment adversely affects nature's ability to dispose it. There are many types of pollution such as air pollution, soil pollution, water pollution, nuclear pollution and oil pollution Akaeze (2001). A pollutant is something which adversely interferes with health, comfort, property or environments of the people. Generally, most pollutants are introduced into the environment as sewages, waste, accidental discharge and as compound used to protect plants and animals. Open dumps are the oldest and most common way of disposing of solid wastes, although in recent years thousands have been closed, many are still being used. In many cases they are located wherever land is available without regard to safety, health hazard, and aesthetic degradation. The waste is often piled as high as equipment allows. In some instances the refuse is ignited and allowed to burn. In others, the refuse was periodically leveled and compacted. Open dumps tend to create a nuisance by being unsightly breading pests, creating a health hazard, polluting the air and polluting ground water and surface water Akaeze (2001).

Landfill leachates can be defined as any liquid material that drains from land or stockpiled materials and contain elevated concentrations of undesirable materials that it has passed through (Henry and Heinke, 1996). Leachate from a dumpsite varies widely in composition, depending on the age of the dumpsite and the type of waste that it contains (Henry and Heinke, 1996). It usually contains both dissolved and suspended material. The generation of leachate is caused by precipitation, percolation through waste deposited in a landfill. Once in contact with decomposing solid waste, the percolating water becomes contaminated and it then flows out of the waste material, it is termed leachate (Christensen et al., 1992). Additional leachate volume is produced during the decomposition of carbonaceous materials, producing a range of other materials including methane, carbondioxide and a complex mixture of organic acids, aldehydes, alcohols and simple sugars. Pollution of groundwater by leachates from dumpsites have been recognized (Hem, 1989; Butow et al., 1989; Alloway and Ayres, 1997; Clark, 2006).The authors described dumpsite practices as the disposal of solid wastes by infilling depression on land. The depressions into which solid wastes are dumped include, valleys, (abandoned) sites of quarries, excavations or sometimes a selected portion within the residential and commercial areas in many urban settlements where the capacity to collect, process, dispose or re-use solid waste in a cost-efficient, safe manner is often limited by available technological and managerial capacities. In developing countries, several metric tons of garbage are left uncollected along the streets, acting as breeding grounds for pests that spread diseases clogging drains and creating a related health and infrastructural problems. The practice of dumpsites system as a method of waste disposal in many countries is usually far from standard recommendations (Adewale, 2009). A standardized dumpsites system involves carefully selected location and is usually constructed and maintained by means of engineering techniques, ensuring minimized pollution of air, water, soil and risks to man and animals. Landfilling involves "placing" waste in line pit or a mound with appropriate means of leachate and landfill gas control (Alloway and Ayres, 1997). Dumpsites in developing countries context is usually an unlined shallow hollow (often not deeper than $50 \mathrm{~cm}$ ). Zurbrugg et al., (2003) referred to it as "dumps" which receive solid wastes in a more or less uncontrolled manner, making uneconomical use of the available space which allows free access to waste pickers, animals and flies, and often produce unpleasant and hazardous smoke from slow-burning fire. 
Besides, it has been revealed that even the lines (protected) dumpsites have been inadequate in the prevention of groundwater contamination (Lee and Lee, 2005).

Open dumpsite is almost the available option for solid waste disposal,. Financial and institutional constraints are the reasons for this in developing countries especially where local governments are weak, under financed and rapid population growth persist (Nanon, 2000; Elaigwu et al, 2007). Acidification and nitrification of ground water have been linked to dumpsite around their outlets while a number of dumpsites have been implicated for bacteria contamination of drinking water (Torres et al, 1991) in some cases, causing poisoning, cancer, heart diseases and teratogenic abnormalities (Siasu, 2008). These waste products are dumped in untreated, posing environmental risk to life in the area and the entire population. Landfill is a practice adopted as a substitute to ocean outfall of sewage, domestic and industrial waste, after the outlawing and termination of latter due to its effects on the lives in the ocean. The ocean outfall causes introduction of pollutants into the food-web through bioaccumulation, changes in the biotic diversity and introduction of persistent organic compounds (like PAHS) into the marine environment. However, with the termination of ocean outfall, in USA (1992), as a result of Ocean Disposal Ban Act' of 1988 (Adriano, 2001) and in the European Union under the urban waste water treated and directive (European Union, 2000), there has been a growing concern on the environmental safety of landfill application of waste products such as long term building of heavy metals in the soil, effects on groundwater and pathogenic effects (Parson et al, 2004; Cheng, et al, 2004; Karrasch et al, 2006;). The trace metals investigated in this study have been implicated for various human health problems even at trace-levels (Aluko et al., 2002). Apart from the contamination of soil and agricultural land by other elements, lead alone has a poisoning effect (Akaeze, 2001). The aims and of this work are to determine the levels of trace metal concentrations in leachate from open dumpsite, with a view to estimate the polluting effects and to suggest a sustainable cost effective and environmental friendly method of treatment.

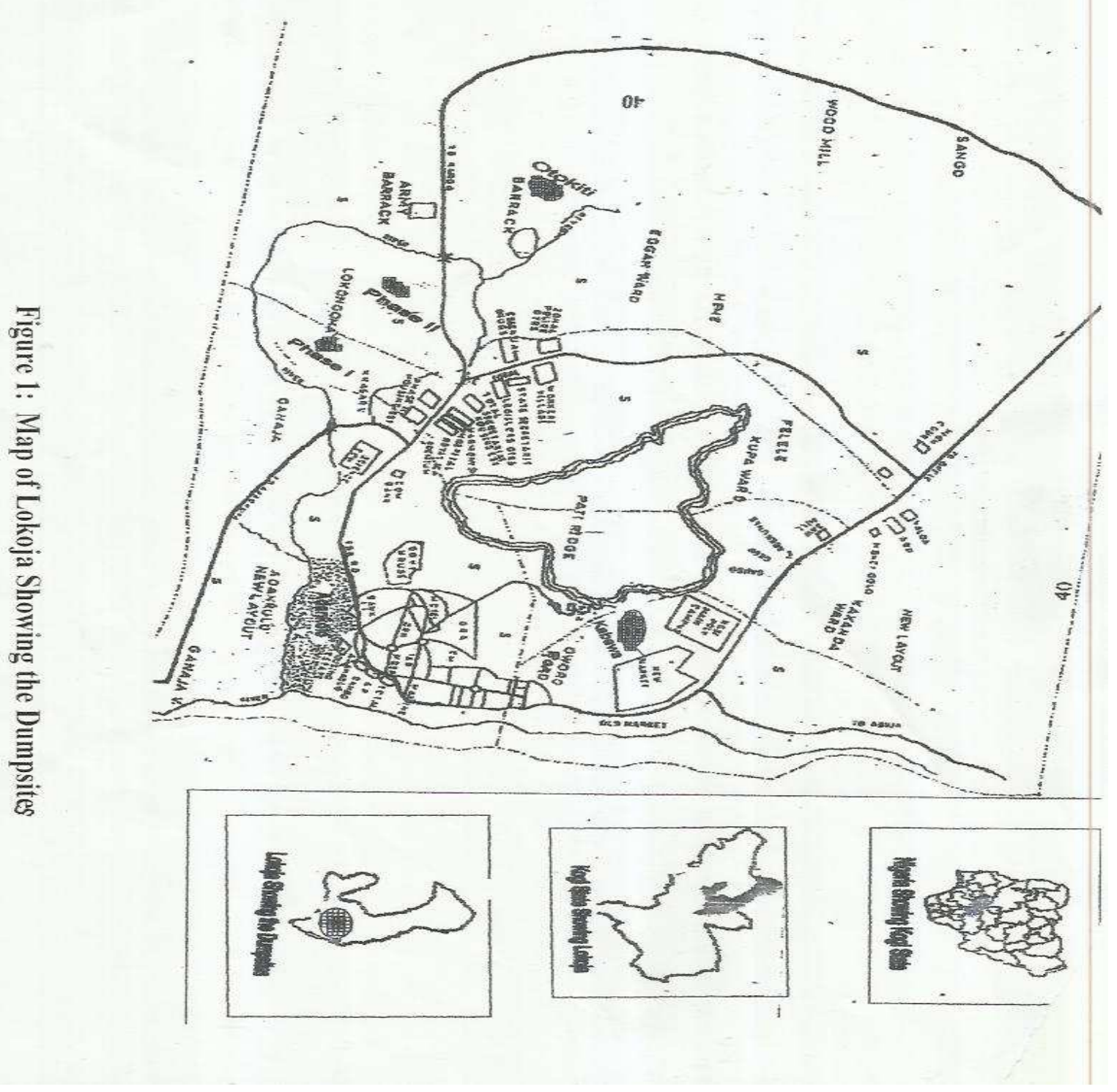




\section{MATERIALS AND METHODS}

In the preparation of reagents, chemicals of analytical grade purity and distilled water were used. All glass wares were washed with detergent and rinsed with distilled water before drying in the oven at $105^{\circ} \mathrm{C}$. All weightings were on Toledo ABS4 analytical weighing balance.

\section{Study Site}

Lokoja is the capital of Kogi State, in the middle belt region of Nigeria. It is located on latitude $7^{0} 49^{\prime \prime}$ and longitude $6^{0} 45^{\prime \prime}$. The city has an area of about $318 \mathrm{~km}^{2}$ with estimated population of 195,261.

\section{Sampling}

Leachate drains were constructed to collect effluents from the waste mass into a pond by gravity during the rainy season (August-October, 2010). Five dumpsites were identified within Lokoja municipal for this study (Figure 1). They include: Kabawa, Lokongoma phase I, Lokongoma phase II, Otokiti and Adankolo dumpsites). The samples taken from 5 sampling points across each of the 5 dumpsites. Leachate samples were collected in plastic containers previously cleaned by washing in non-ionic detergent, rinsed with tap water and later soaked in $10 \% \mathrm{HNO}_{3}$ for 24 hours and finally rinsed with de-ionized water prior to usage. During sampling, bottles were rinsed with sample leachate three times and then filled to the brim.

\section{Sample Treatment}

The samples collected were preserved by addition of concentrated $\mathrm{HNO}_{3}\left(1 \mathrm{~cm}^{3}\right.$ of $\mathrm{HNO}_{3}$ per $100 \mathrm{~cm}^{3}$ of leachate sample) this is to adjust the $\mathrm{pH}$ of the sample to less than 2, to arrest microbial activities and prevent loss of the metals by precipitation and absorption. All samples collected were kept in ice chest to maintain them at a temperature below $4^{\circ} \mathrm{C}$ during transport from the field to the laboratory. They were kept in refrigerator under the laboratory condition till analyses were completed. The time between sampling and analyses of samples were kept short and between recommended time by the standard method.

\section{Digestion of leachate samples}

Leachates $\left(100 \mathrm{~cm}^{3}\right)$ sample was transferred into a beaker and $5 \mathrm{~cm}^{3}$ of $6 \mathrm{M}$ nitric acid was added. The beaker with the content was placed on a hot plate and evaporated down to about $20 \mathrm{~cm}^{3}$. The beaker was cooled and another $5 \mathrm{~cm}^{3} 6 \mathrm{M}$ nitric acid was also added. The heating was continued, and then small portion of nitric acid was added until the solution appeared light coloured and clear. The beaker wall and watch glass were washed with water and the sample was filtered to remove any insoluble materials that could clog the atomizer. The volume was adjusted to $100 \mathrm{~cm}^{3}$ with distilled water (Ademoroti, 1996). Determination of trace metals (Iron, copper, zinc, lead, nickel, cadmium, and manganese) in the leachate sample was done using Buck scientific model 210VGP Atomic Absorption spectrometer (AAS) equipment with a continued source background correction. The result of each sample was the average of three replicate readings. The water used as blank was digested using the above procedures. A calibration curve of absorbance against concentration was plotted from the standards. The concentration of each element under investigation was determined from the calibration curve of its standard by extrapolation (Ademoroti, 1996).

\section{RESULTS AND DISCUSSION \\ Trace Metals in Dumpsite Leachate}

The distribution pattern of iron is unimodal and is skewed towards low frequency of high concentration with a mean and standard deviation of $73.60 \pm 8.50 \mathrm{mg} / \mathrm{l}$. The highest concentration of iron was observed at Kabawa dumpsite whereas the lowest concentration was observed at Otokiti dumpsite. These value exceeded the control value of $15.5 \pm 2.70 \mathrm{mg} / \mathrm{l}$ and much higher than the allowable limit of 20.0mg/l set by FEPA (1991) and WHO (1997). The high level of iron in the leachate samples indicates that apart from background concentration, iron and steel scraps are also dumped in the dumpsite. The dark brown colour of the leachate is mainly attributed to oxidation of ferrous to ferric hydroxide colloids and complexes with fulvic/humic substances (Chu et al, 1994).

The distribution pattern of lead is multimodal and is skewed towards high frequency of low concentration with a mean and standard deviation of $1.55 \pm 0.097 \mathrm{mg} / \mathrm{l}$. The highest concentration of lead was observed at Adankolo dumpsite while the lowest concentration was observed at Lokongoma Phase II dumpsite. These values are much higher than control values and also higher than the allowable limits of less than $1 \mathrm{mg} / \mathrm{l}$ set by FEPA and WHO. The major source of lead pollution is industrial source (Dara, 1993), consequently the significant increase in the concentration of lead at Adankolo dumpsite where much economic and industrial activities concentrate is not surprising. Similarly the low concentration of lead at Lokongoma Phase II dumpsite is due to the reduction in the volume of industrial wastes introduced into the dumpsite. Aluko et al, (2002) reported the mean concentration of lead in leachate at Ibadan dumpsite to range from $1.34 \mathrm{mg} / \mathrm{l}$ to $1.693 \mathrm{mg} / \mathrm{l}$. The pollution of soil by lead is a very serious problem that has been given much attention by environmental chemist. This is due to the fact that lead is cumulative pollutant (Dara, 1993) and the continuous disposal of lead containing waste into the environment should be discouraged.

The distribution of zinc is bimodal and is skewed towards low frequency of high concentration with a mean and standard deviation of $2.41 \pm 0.42 \mathrm{mg} / \mathrm{l}$. The highest concentration of zinc was observed at Adankolo dumpsite leachate while the lowest concentration was observed at Kabawa dumpsite leachate. These values are higher than the control value and much higher than FEPA and WHO standard. The high level of zinc in the leachates shows that the dumpsite receives waste from batteries and florescent lamps. Aluko et al, (2003) reported that the mean concentration of zinc in leachate sample at some dumpsites in Ibadan ranged from $1.423 \mathrm{mg} / \mathrm{l}$ to $2.428 \mathrm{mg} / \mathrm{l}$ which are similar to the levels obtained in this study. 
The distribution of manganese is unimodal and is skewed towards low frequency of high concentration with a mean and standard deviation of $16.53 \pm 3.09 \mathrm{mg} / \mathrm{l}$. The highest concentration of manganese was observed at Otokiti dumpsite leachate while the lowest concentration was observed in Adankolo dumpsite leachate. These values are higher than the control value and much higher than FEPA and WHO standards. Dara (1993) reported that manganese may be found in most soils since it is one of the elements in the earth crust hence the observed high concentration of manganese might have been largely due to background concentration.

The distribution of copper is unimodal and is skewed towards low frequency of high concentration with a mean and standard deviation of $1.00 \pm 0.21 \mathrm{mg} / \mathrm{l}$. The highest concentration of copper was observed at Otokiti dumpsite leachate while the lowest was observed at Lokongoma Phase II dumpsite leachate. These values are slightly higher than the control value and also higher than the allowable limit set by FEPA (1991) and WHO (1997). It has been reported by Dara (1993) that a biodegradable wastes introduces metallic copper into soil at a level slightly above the natural level for soils. This might be responsible for the high concentration of copper in soil at the dumpsite leachate. Also the high concentration of copper might be due to the fact that wastes at dumpsites in Otokiti contain the highest quantity of copper containing waste. Ademoroti (1996) listed categories of copper containing waste to include industrial wastes agricultural wastes and some domestic wastes. These were also found at the dumpsite.

The distribution of nickel is unimodal and is skewed towards low frequency of high concentration with a mean and standard deviation of $0.42 \pm 0.094 \mathrm{mg} / \mathrm{l}$. The highest concentration of nickel was observed at Otokiti dumpsite while Adankolo dumpsite was the lowest. These values were found to be below the permissible limit of $1.0 \mathrm{mg} / \mathrm{l}$ for waste disposal at surface water. The presence of nickel at dumpsite leachate suggests that the element might have been introduced by biodegradation of nickel containing waste into the environment. Also the uncontrolled disposal of waste into the environment can significantly increase background concentration of nickel in the environment. Similar findings have been reported by (Aluko et al, 2003; Eddy et al, 2006). The distribution is unimodal and it is skewed towards low frequency of high concentration with a mean and standard deviation of $0.2 \pm 0.053 \mathrm{mg} / \mathrm{l}$. The concentration of cadmium in the dumpsites was observed to be below the permissible limit of $1.0 \mathrm{mg} / \mathrm{l}$ for waste disposal at surface water. High concentration of cadmium was observed at Otokiti and Adankolo dumpsites leachate respectively, while low value was found at Lokongoma Phase II.

Table 1: Trace Metals Concentration of Leachates from Open Dumpsite in Lokoja, Kogi State Nigeria

\begin{tabular}{lccccc}
\hline PARAMETER & KABAWA & $\begin{array}{c}\text { PHASE I } \\
\text { LOKONGOMA }\end{array}$ & $\begin{array}{c}\text { PHASE II } \\
\text { LOKONGOMA }\end{array}$ & OTOKITI & ADANKOLO \\
\hline IRON (mg/L) & $83.52 \pm 0.16$ & $70.61 \pm 0.0045$ & $68.70 \pm 0.46$ & $64.28 \pm 1.04$ & $74.00 \pm 0.18$ \\
ZINC (mg/L) & $2,12 \pm 0.040$ & $2.24 \pm 0.035$ & $2.16 \pm 0.090$ & $2.37 \pm 0.11$ & $3.16 \pm 0.070$ \\
LEAD (mg/L) & $1.62 \pm 0.016$ & $1.54 \pm 0.018$ & $1.36 \pm 0.052$ & $1.58 \pm 0.065$ & $1.64 \pm 0.058$ \\
COPPER (mg/L) & $1.11 \pm 0.022$ & $0.92 \pm 0.019$ & $0.78 \pm 0.022$ & $1.33 \pm 0.074$ & $0.88 \pm 0.025$ \\
NICKEL (mg/L) & $0.45 \pm 0.017$ & $0.41 \pm 0.019$ & $0.36 \pm 0.26$ & $0.58 \pm 0.045$ & $0.30 \pm 0.011$ \\
CADMIUM (mg/L) & $0.22 \pm 0.029$ & $0.28 \pm 0,011$ & $0.19 \pm 0.015$ & $0.32 \pm 0.026$ & $0.32 \pm 0.024$ \\
MANGANESE(mg/L) & $15.52 \pm 0.23$ & $12.74 \pm 0.089$ & $16.57 \pm 0.211$ & $17.37 \pm 0.15$ & $10.50 \pm 0.33$ \\
\hline
\end{tabular}

Table 2: Trace Metals Concentration of Leachates from Control Site, FEPA \& WHO Standards

\begin{tabular}{lcc}
\hline TRACE METALS & CONTROL SAMPLE & FEPA \& WHO STANDARD \\
\hline IRON & $15.5 \pm 2.7$ & 20.00 \\
ZINC & $0.03 \pm 0.01$ & $<1$ \\
LEAD & $0.01 \pm 0.01$ & $<1$ \\
COPPER & $0.002 \pm 0.001$ & $<0.2$ \\
NICKEL & $0.02 \pm 0.01$ & $<1$ \\
CADMIUM & ND & $<1$ \\
MANGANESE & $2.75 \pm 1.02$ & $<5.0$ \\
\hline
\end{tabular}

\section{CONCLUSION}

Optimal leachate treatment in order to fully reduce the negative impact on the environment is a challenge today. But the complexity of the leachate composition makes it very difficult to formulate general recommendations. Variations in leachates, in particular their variation both over time and from site to site, means that the most appropriate treatment should be simple, universal and adaptable. Therefore some remedial measures are required to prevent for their contamination. This can be achieved by the management of the leachate generation, its treatment and subsequent recycling throughout the waste. 


\section{REFERENCES}

Ademoroti, C.M.A. (1996). Standard Method for Water and Effluents Analysis. Foludex press Ltd, Ibadan. Pp 22-23, 44-54, 111-112.

Adewale, A.T. (2009). Waste Management Towards Sustainable Development in Nigeria: A Case Study of Lagos State Int. NGO J. 4(4): 173179.

Adriano, D.C. (2001). Trace Elements in Terrestrial Environments $2^{\text {nd }}$ ed. New York; Springerverlag Pp 87-92.

Akaeze C.S (2001). Elemental Composition of Soil in Some Dumpsites. Electronic Journal of Environmental and Food Chemistry ISSN. 1579-433. 1351

Akpan L.T (2001). Solid waste Generation, Control and Management Strategies in Uyo Municipality. A Research Paper Submitted to the Department of Environmental Technology, Oweri

Alloway, B.Jand Ayres, D.C. (1997). Chemical Principle of Environmental Pollution. In: Wastes and their disposal, $2^{\text {nd }}$ ed..., Blackie Acad Professional, London UK, Pp 353-357.

Aluko, O.O; Sridhar, M.K.C and Oluwande P.A. (2003). Characterization of leachates from municipal solid waste landfill site in Ibadan Nigeria. Journal of Environmental Health Research 2(1) 32-37.

Butow, E; Holzbecher, E and Kob, E. (1989). Approach to Model the Transport of Leachates from a Landfill Site Including Geochemical Processes Contaminant Transport in Ground Water. Kobus and Kinzelbach, Balkeima, Rotterdam. Pp 183190.

Cheng, Z; Zheng, Y; Morttock, R and Van Green, A. (2004). Rapid Multi-Element Analysis of groundwater by High-Resolution Inductively Coupled Plasma Mass-Spectrometry. Anal. Bioanal. Chem 329(3) 512-518.

Christensen, T.H.; Cossu R, and Stegmann, R. (1992). Landfilling of Waste Leachate. London Elsevier Applied Science. Pp 456 - 458

Chu, L.M.; Cheung K. C, and Wong, M. H. (1994). Variations in the Chemical Properties of Landfill Leachate. Environ Management...; 18: 105-117.

Clark, J. (2006). Rivers and their Catchments: Impact of Landfill on Water Quality, Earth Sci-Branch Scottish Natural Heritage. Pp 2.

Dara S.S (1993). Effect of Leaching on Heavy Metals Concentration of Soil in Some Dumpsites. African Journal of Environ Science and Technology 4(8); 495-499

Eddy, N.O.; Odoemelem, S.A and Mbaba A. (2006). Elemental Composition of Soil in Some Dumpsites. Electronic Journal of
Environmental, Agricultural and Food Chemistry 13:6: 1349-1362.

Elaigwu, S.E; Ajibola, V.O and Folarami, F.M. (2007). Studies on the Impact of Municipal Wastes Dumps on Surrounding soil and air Quality of two Cities in Northern Nigeria. J. Appl. Sci 7(3): 421-425.

Etepko E.I (1999). Elemental Composition of soil in some dumpsites. Electron J. Environ Agric. Food Chem. 23:12:204 -210

European Union (2000). Directive of the European Parliament and of the Council 2000/60/EC. Establishing a framework for Community Action in the Field of Water Policy. PE-CONS 3639/1/00 Rev.1.

FEPA, (1991) . Federal Environmental Protection Agency. National Guidelines and Standards for Industrial Effluents and Water Quality Tests. FEPA Nigeria Official Gazette, Nigeria.

Hem, J.D. (1989). Study and Interpretation of the Chemical Characteristics of Natural Water, US geological surveys, Water-supply Paper, 2254.

Henry, J and Heinke, G. (1996). Environmental Science and Engineering Prentice Hall, Yorkshire. 6:2:44 -46

Karrasch, B; Parra, O; Cid, H; Mehrens, M; Pacheco, $P$; Urrutia, $\mathrm{R}$; Valdovinos, $\mathrm{C}$ and

Lee, G.F and Lee, J.A. (2005). Municipal solid waste landfills water quality issues: Water Encyclopedia: Water Quality and Resource Department John Wiley NJ. Pp. 163-169.

Nnuoon, F. (2000). Urban Organic Waste Market: Responding to Change in Hubli-Dharwad, India, Habitat Int: 24: 347-360.

Parsons, T.; Maita, Y and Lalli, C. (1984). A manual of Chemical and Biological Methods for Seawater Analysis. Oxford Pergamon press. Pp 22-85.

Siasu, G.L. (2008). Assessing the Effect of a Dumpsite to Ground Water Quality in Payatas, Philippines. Am, J. Environ. Sci. 4(4). 276280.

Torres, E; Subida, R and Rabuco, L. (1991). Health Profile of Child Scavengers in Snokey Maintain, Balut, Tondo, Mnila. German Agency for Technical Cooperation International Labour Organization/College of Public Health, University of the Philippians; Manila.

WHO (World Health Organization). 1997. Guideline for Drinking Water Quality, $2^{\text {nd }}$ ed...; vol. 2. Health Criteria and other Supporting Information, World Health Organization, Geneva, 940-949.

Zurbrugg, C; SANDEC and EAWAG (2003). Solid Waste Management in Developing countries; SWM introducing text on www.sanicon.net. 5. 